\title{
Does higher remuneration equal higher job performance?: an empirical assessment of the need-progression proposition in selected need theories
}

\author{
Cecil A. Arnolds* \& Christo Boshoff \\ Department of Business Management, University of Port Elizabeth, P.O. Box 1600, Port Elizabeth, 6000 South Africa \\ ecacaa@upe.ac.za \& ecahcb@upe.ac.za
}

Received March 1999

\begin{abstract}
Improving employee job performance is central to almost all management activity. To this end, the need theories of motivation have been the foundation of many interventions to increase employee job performance. Important elements of these theories. especially the progressive satisfaction of needs from lower-order to higher-order needs and the impact thereof on behavioural outcomes on different organisational levels, have been questioned. This uncertainty has implications for what strategies managers would explore to eliminate need deficiencies on the differrent oganisational levels to motivate employees. In assessing the influence of need satisfactions on various behavioural outcomes in previous studies, regression analysis was used to statistically analyse the data. This technique identifies significant correlations, but not causal relationships among variables. It has been suggested that the identification of a causal link between the satisfaction of various needs and behavioural outcomes could shed more light on the motivation of behaviour. In the present study a more advanced technique - structural equation analysis - that identifies what variable causes a certain outcome, is used to measure the influence of various need satisfactions on performance intentions. The empirical results support the need-progression proposition, because the influence of need satisfaction on performance intentions is not the same for employees at different organisational levels.
\end{abstract}

* Author to whom correspondence should be addressed.

\section{Introduction}

It is a well accepted premise that any business concerm needs productive employees (manpower) to produce output of acceptable quality to realise its economic, societal and employee-related goals. In other words, any enterprise needs employees who are willing and committed to exerting high levels of effort, but who also have the intentions to achieve optimal job performance. In short, motivating employees to improve their job performance is central to almost all management activity (Blunt \& Jones, 1992: 277).

Various categories of motivation theories have been advanced to understand and enhance job performance. These theories include the content theories (for example, Maslow's need hierarchy, Herzberg's two-factor theory and McClelland's achievement theory), the process theories (for example, Vroom's expectancy theory, Porter and Lawler's expectancy theory and Adam's equity theory) and the reinforcement theory based on the Thomdike principle of law of effect. The latter principle simply means that people tend to repeat behaviour that leads to a pleasant result.

The content theories, also called the need theories, have received more attention in research studies than the other motivation theories, because they have been seen as '... of the most enduring ways to understand motivation' (Aram \& Piraino, 1978: 179). The need theories suggest that individuals are motivated to increase their job performance by their individual striving to satisfy certain needs. It is generally accepted in industrial psychology and management circles that a psychological contract between an individual and the enterprise is entered into when an individual takes up employment. According to this contract the employee undertakes to exhibit certain behaviours and exert certain efforts to assist the enterprise in reaching its set goals. This performance is however rendered with the expectation that the enterprise will counter perform by satisfying certain needs of the employee. Need satisfaction thus forms the basis of the job performance of employees in business enterprise. The present study focuses on the relationship between need satisfaction and job performance against the background of three need theories, namely the Maslow, Alderfer and McClelland need theories.

\section{Need theories selected for investigation}

The debate as to whether increased monetary remuneration motivates all employees to enhanced job performance still rages today. It is the belief of some managers that employees' job performance is to a large extent determined by their monetary rewards. Interviews conducted with employees from a variety of business organisations however suggest that other intrinsic rewards such as respect, status, achievement and acceptance are rewards many of them value highly. A cursory glance at articles on motivation published by management consultants suggests that many consultants are led in their advice to managers by diverse need theories such as those proposed by Maslow, Herzberg, McGregor and McClelland. Although there appears to be a convergence on the notion of need satisfaction as the basis for increased job performance, there is no motivation theory consistently touted by managers. A need therefore exists for the identification of a theory that could be consistently applied to motivate employees at all organisational levels, or to investigate whether the current motivation theories used by managers are valid. 
The present study focuses on the need theory of motivation as espoused by Maslow (1943). because it is one of the most widely used motivation theories (Stahl. 1986: 39) and on the ERG theon of Clayton Alderfer (1969), because it was one of the first empirical assessments of some of the basic premises of Maslou's theory with the aim of improving the latter. The question of whether the Alderfer theory is indeed an improvement on Maslow's theory therefore needs to be investigated. David McClelland's achievement theory (1962) is unique, as it is the only theory that highlights the achievement need as a learned need (all persons therefore possess it) and the only theory that specifically links this need to job performance and the economic prosperity of people and countries. The need for achievement is one of the esteem needs of Maslow. To summarise: the present study focuses on the above-mentioned theories to ascertain whether the needs proposed by Maslow and Alderfer are indeed the main motivators of employee job performance and whether all employees are motivated by the satisfaction of the need to achieve.

Maslow's theory contends that man has five basic categories of needs which are ranked and satisfied on a hierarchy ranging from lower-order to higher-order needs - first the physiological needs, followed by the safety and security, affiliation, esteem and self-actualisation needs respectively. Although Maslow's theory is intuitively appealing, various criticisms have been levelled at it. De Cenzo \& Robbins (1988: 315 ), for instance, are of the opinion that Maslow did not provide sufficient empirical substantiation for his theory. Steers \& Porter (1991: 38) conclude from a review of seventeen studies that no conclusive evidence has emerged to support two central aspects of Maslow's theory. Firstly, that no evidence emerged that human needs are classified in five distinct categories, or that these categories are structured in any special hierarchy (Steers \& Porter, 1991). Secondly, that lower-level needs must be satisfied before higher-level needs are activated. A central aspect of Maslow's theory. namely the progressive satisfaction of needs on a hierarchy from lower-order to higher-order needs (in other words, need-progression), is thus questioned.

A variety of research studies have reiated need-progression to job level ascendance (Haywood-Farmer \& Leenders, 1986; Hong, Yang, Wang, Chiou, Sun \& Huang, 1995). It has been suggested that at lower levels of employment the focus of employees would be on endeavours to satisfy the lower-order needs (namely physiological, safety and security, and affiliation) and as employees move up in the organisational structure their focus changes to the satisfaction of the higher-order needs (esteem and self-actualisation).

An important motivation theory namely that of Alderfer (1969) disagrees with the need-progression proposition. According to Alderfer's ERG theory, man is motivated by three groups of core needs, namely Existence, Relatedness and Growth needs. Alderfer argues that there is no step-by-step progression from lower-order needs to higher-order needs and that more than one need can be operative at the same time.

Another motivation theory at odds with the need-progression proposition is the need theory of McClelland (1962). According to this theory, many needs are acquired through the individual's interaction with culture. McClelland singled out three needs that are important motivators of behaviour, namely the needs for achievement. power and affiliation. It has been suggested that due to the learned nature of these needs, different people have different configurations of needs (Ivancevich \& Matteson, 1999). In other words. a particular configuration at a particular time can include both higher and lower-order needs, thus debunking the need-progression theory.

Much of the research on the job level ascendance-need satisfaction relationship, however, appears to favour the needprogression proposition. Porter (1962, 1963), for instance, conducted a series of studies on the influence of job level on need satisfaction. These studies have shown that need fulfilment deficiency decreases as employees move from lower management to middle and top management. Porter (1962: 383) concludes that the vertical location of the manager in the organisational structure is a determinant of the degree to which that manager feels he can satisfy certain psychological needs, more particularly the higher-order needs (esteem, autonomy and self-actualisation).

In a follow-up study Porter (1963) addressed the doubt with regard to the progressive satisfaction of needs as job level in creases. Porter's (1963: 148) results indicated that as job level decreased from top to lower management, autonomy. esteem and self-actualisation needs were less likely to be fulfilled There were, however, no significant differences, between the various job levels as far as security and social needs were concerned.

Hayward-Farmer \& Leenders (1986) investigated the psychological need profiles of purchasing managers over a period of ten years. They found that the satisfaction of physiological, security and respect needs decrease in importance over time, while the satisfaction of relationship and self-actualisation needs became more satisfied over the same period. This finding supports the notion that as job level increases, so does the importance of higher-order needs.

Hong et al. (1995: 14) has reported that employees on different job levels do indeed emphasise different needs at different levels. Their empirical results indicated that lowerlevel employees expressed a stronger concern for better working conditions and security needs, lower-level managers (supervisors) emphasised monetary and security needs, while middle managers stressed individual development needs. Top managers, however, perceived their job performances as unrelated to needs such as monetary rewards, security and better working conditions. The latter finding could indicate that top level executives are motivated by the higher-level needs of achievement, power and self-actualisation rather than the mentioned lower-order needs. Hong et al.'s (1995) study thus seems to provide empirical support for the notion that there exists a positive relationship between job level ascendance and need-progression from lower to higher-order needs.

The apparent disagreement between the theories of Alderfer and McClelland and research findings discussed above on the issue of need-progression needs to be investigated as it appears that industrial psychologists and human resource management researchers may wrongly utilise motivation and reward strategies based on this contention (Prokopenko, 1987: 208; Stein \& Hollowitz, 1992: 20). In other words, the question that needs to be addressed is whether managers are 
pursuing the appropriate motivational strategies if the relationship between need-progression, job level and employee job performance is unclear.

\section{A proposed methodology to investigate need-pro- gression}

Much of the uncertainty about the relevance of motivational theories, need-progression and their impact on job performance can be attributed to the relatively unsophisticated data analysis techniques used to date. In the studies of HaywardFarmer \& Leenders (1986), Hong et al. (1995), in fact, in most of the research conducted on employee motivation, regression analysis was used to statistically analyse the data. This technique indicates the correlation between a change in one variable and a change in another variable, but does not show that the change in the first variable causes the change in the other variable. It would be an improvement in motivational research if motivational interventionists or consultants can say with a greater degree of accuracy that a certain need satisfaction causes a certain performance behaviour. Wahba \& Bridwell (1976: 231) suggested that a methodology which could prove the causal relationship between need satisfaction and outcome variables, such as job performance, would be an ideal method to test Maslow's motivation theory and remove remaining doubt about the need-progression contention. A relatively new technique, called structural equation analysis, which goes a long way in identifying causal relationships among variables, has recently emerged and has been applied in the present study to enhance the understanding of the motivation of behaviour. The present study suggests that the different impact of need satisfactions on the behavioural outcomes of people on different organisational levels may suggest support for the need-progression theory.

\section{Objectives}

The broad objective of the study is to investigate the proposition that employees progressively satisfy needs on a hierarchy ranging from lower to higher-order needs and to assess how this need-progression impacts on employee job performance. The study investigates need-progression by assessing the causal relationships between the Maslow, Alderfer and McClelland need theories, on the one hand, and performance intentions (as a measure of employee job performance) on the other hand.

\section{Hypotheses}

The preceding literature review points to the notion that the job performance of higher-level managers would be significantly influenced by higher-order need satisfaction, while lower-order need satisfaction would be the dominant determinant of the job performance of lower-level employees. More specifically, the literature suggest that top managers would be primarily motivated by the satisfaction of selfactualisation and growth needs, middle managers by esteem (achievement and power) need satisfaction and frontline employees by the satisfaction of affiliation, safety and security and physiological needs.
Based on this review the following hypotheses were formulated:

$\mathrm{H}^{1}$ : Higher-order need satisfaction (as measured by self-actualisation and growth needs) exerts a positive influence on the job performance of top managers.

$\mathrm{H}^{2}$ : Higher-order need satisfaction (as measured by esteem needs) exerts a positive influence on the job performance of middle managers.

$\mathrm{H}^{3}$ : Lower-order need satisfaction (as measured by affiliation, safety and security and physiological needs) exerts a positive influence on the job performance of frontline employees.

The relationships based on the above-mentioned hypotheses are graphically depicted in Figure 1.

\section{Research methodology \\ Sample}

The sample consisted of 304 top managers (response rate = $20.27 \%$ ), 153 middle managers (response rate $=10.2 \%$ ) and 213 frontline employees (response rate $=21.3 \%$ ). This represented an overall response rate of $16.75 \%$. The frontline employee sub-sample includes those non-management groups of employees who are at the frontline of service provision, such as bank tellers, secretaries, sales clerks, security personnel, office staff, library assistants and catering staff and who have no supervisory responsibilities.

\section{Measuring instruments}

The measuring instrument chosen to measure the Maslow needs in this study was developed by Barling (1976). Reliability coefficients ranging from 0.86 to 0.92 were reported. The instrument also exhibited acceptable content and discriminant validity.

A shortened version of Alderfer's (1969) instrument was used to measure the Alderfer existence, relatedness and growth needs. Favourable results on the convergent and discriminant validation and reliability coefficients ranging from 0.64 to 0.88 were reported for the five ERG subscales (Alderfer, 1967: 514; 1969: 169).

An instrument used to measure the McClelland needs, called the Manifest Needs Questionnaire (MNQ), was developed by Steers \& Braunstein (1976). Acceptable levels of convergent, discriminant and predictive validity, as well as test-retest and Cronbach reliability coefficients for the MNQ subscales were reported by Steers \& Braunstein (1976: 258).

Several researchers have described performance intentions as a potent measure or predictor of employee job performance. Performance intention is regarded as a direct motivational determinant of task performance (Hampton, Summer \& Webber, 1982: 378), a strong indication of motivation to produce (Carkhuff, 1986: 61), a prerequisite for peak performance (Sumerlin \& Norman, 1992: 478) and a strong precursor to actual job performance (Shore, Newton \& Thornton, 1990: 64). The instrument used to measure performance intentions in this study was developed by Shore, Newton \& Thornton (1990). It consists of three items modelled after the Michigan Organizational Assessment Questionnaire (MOAQ) of Cammann, Fichman, Jenkins \& Klesh as cited in Shore et al. (1990). One item, namely 'I could do a lot more work if I tried a little harder', from the Cranny, Smith and Stone (1992) 


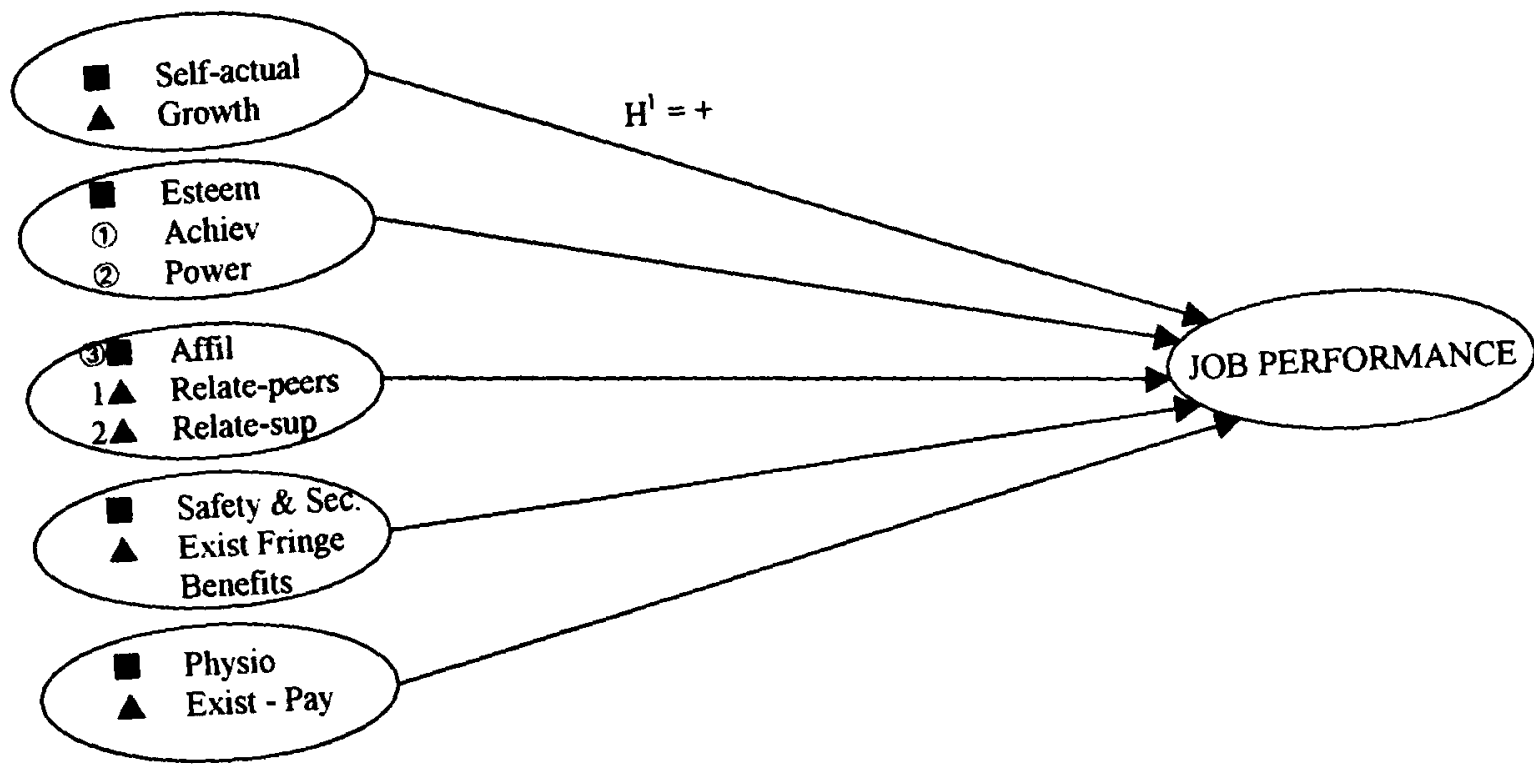

MIDDLE MANAGEMENT

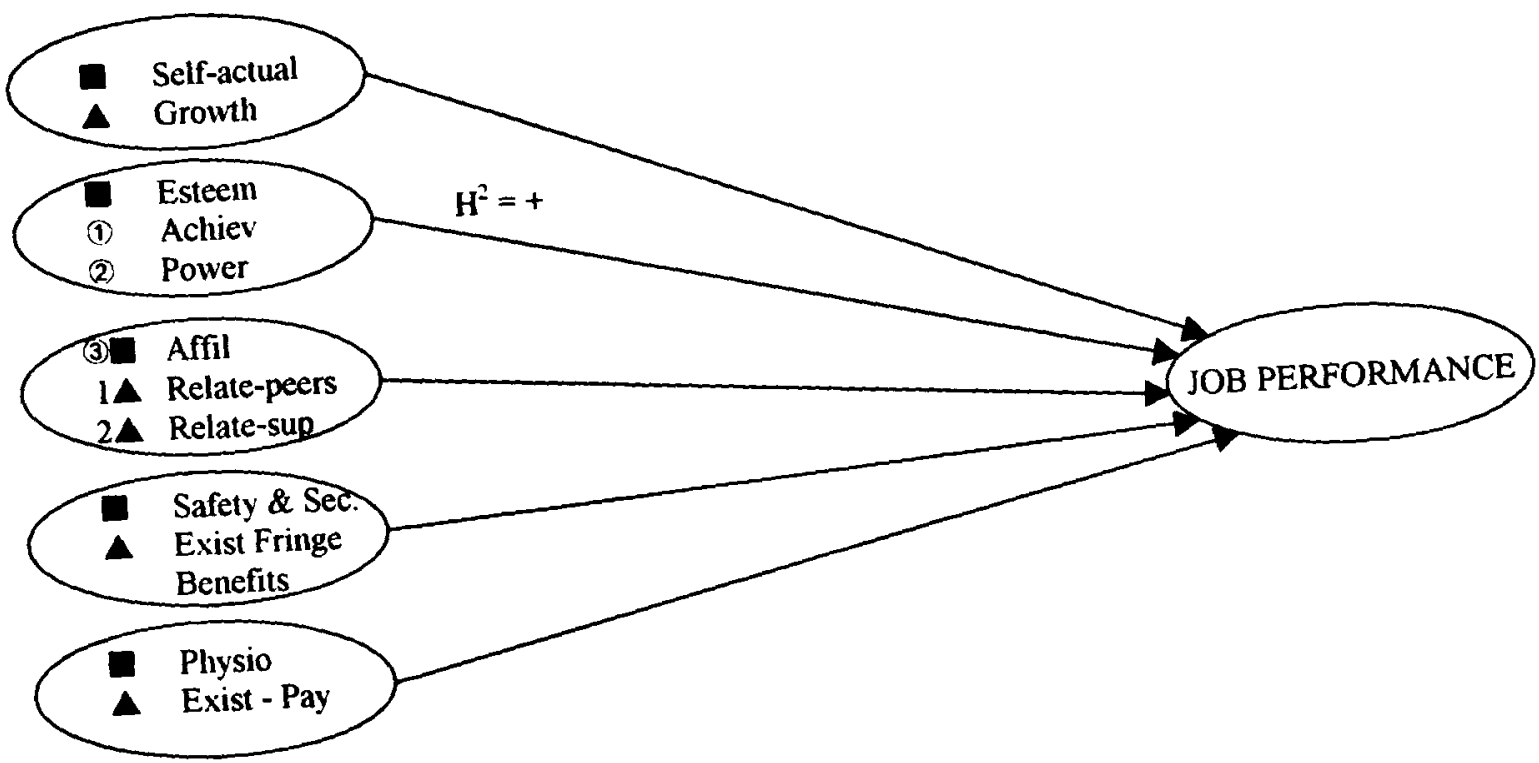

FRONTLINE EMPLOYEES

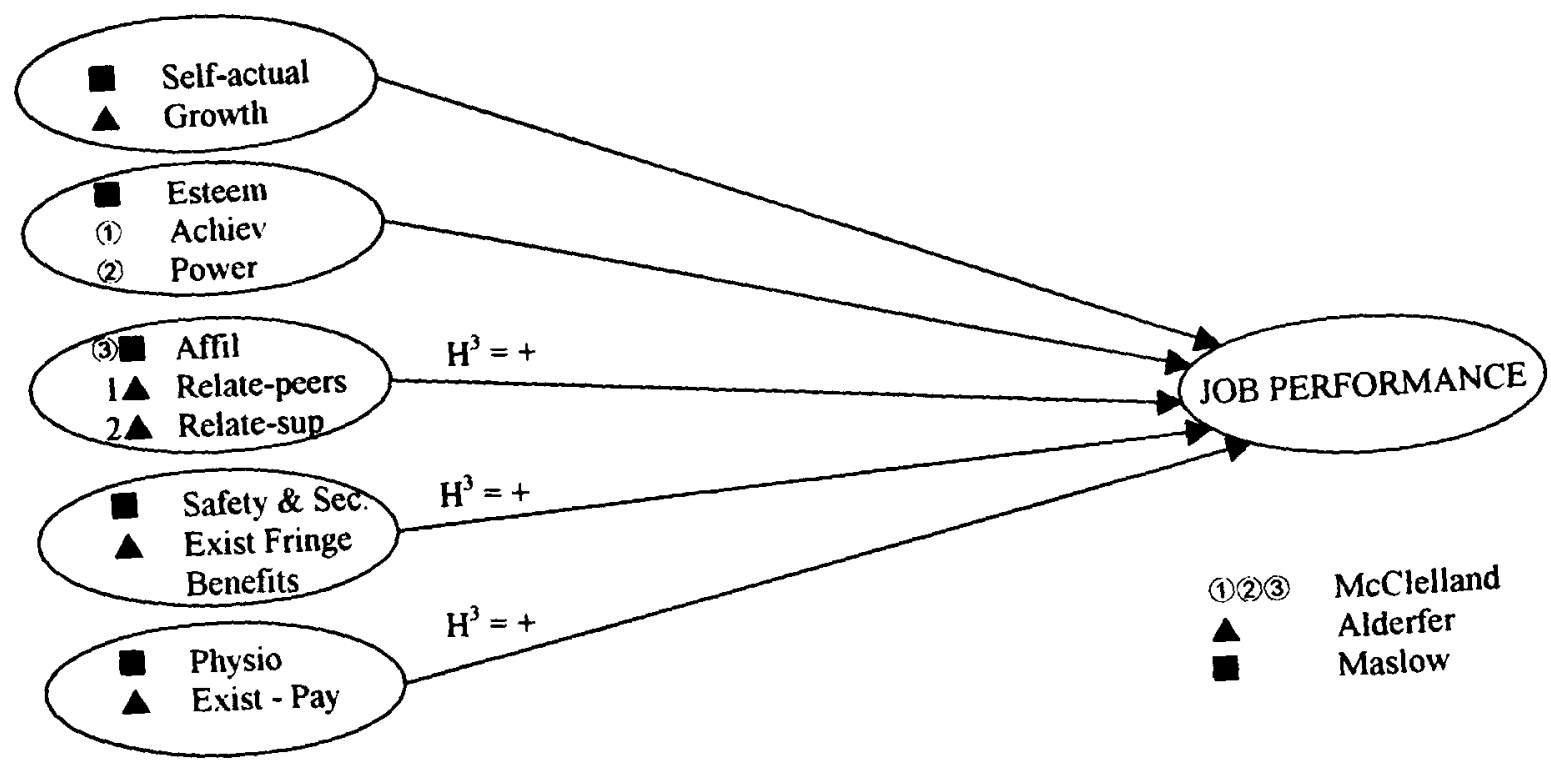

Figure 1 Hypothesised linkages between need satisfaction theories and employee job periormance 
scale was added to make the performance intention scale a 4item one. This was done for reasons of consistency (all other scales, except the $\mathrm{McCl}$ elland scales, comprised four items) and to avoid possible problems during exploratory factor analysis. The reported reliability coefficients, which ranged from 0.60 to 0.84 , are regarded as sufficient to use this instrument to measure the performance intention construct (Shore et al., 1990).

In summary it is evident from the preceding review that instruments with acceptable validity and reliability were used to investigate the variables under scrutiny. Respondents were requested to respond to all questions on a seven-point Likerttype scale.

\section{Data analysis}

\section{Reliability and validity}

Cronbach alpha coefficients were calculated to assess the internal reliability of the measuring instruments. Table 1 indicates acceptable internal reliability coefficients for the instruments used in this study. All the Cronbach reliability coefficients were above 0.580 and thus above the 0.500 cutoff point needed for basic research (Pierce \& Dunham, 1987; Tharenou, 1993).

To assess the discriminant validity of the measuring instruments, three sets of exploratory factor analyses were conducted, using the computer programme BMDP4M (Frane, Jennrich \& Sampson, 1990). Maximum likelihood was speci- fied as the method of factor extraction and a Direct Quartimin oblique rotation of the original factor matrix was used (Jennrich \& Sampson, 1966) in all instances. Table 1 summarises the factor structures for the scales as they emerged from the factor analyses.

Based on the factor analysis results and Cronbach alphas the Maslow esteem needs variable (top management and frontline employee samples), the Maslow safety and security needs variable (middle management sample) and the McClelland affiliation needs variable (top management, middle management and frontline employee samples) were deleted from the theoretical models. Table 1 therefore lists the latent variables that were included in the final theoretical models. These models were then subjected to a structural equation analysis.

\section{Structural equation analysis}

Structural equation analysis, or modelling (SEM) is a multivariate technique combining aspects of multiple regression and factor analysis to estimate a series of interrelated dependence relationships simultaneously (Hair, Anderson, Tatham \& Black, 1995: 625). SEM differs from multiple regression analysis in very important respects. Regression analysis indicates the relative importance of an independent (predictor) variable in predicting the dependent (response) variable, as well as the overall strength of that relationship. In a linear regression model, variables are measured with error and the coefficients represent empirical associations, but not

Table 1 Empirical factor structure

\begin{tabular}{|c|c|c|c|}
\hline Latent variable & Top & Middle & Frontline \\
\hline Maslow physiological needs & $\begin{array}{l}\text { MAPH } 2,4 \\
\alpha=0.617\end{array}$ & $\begin{array}{l}\text { MAPH } 2,3,4 \\
\alpha=0.675\end{array}$ & $\begin{array}{l}\text { MAPH } 1,2,3.4 \\
\alpha=0.627\end{array}$ \\
\hline Maslow safety \& security needs & $\begin{array}{l}\text { MASS } 2.3 .4 \\
\alpha=0.610\end{array}$ & Deleted & $\begin{array}{l}\text { MASS } 1.2 .3 \\
\alpha=0.582\end{array}$ \\
\hline Maslow affiliation needs & $\begin{array}{l}\text { MAAF } 1,2,3.4 \\
\alpha=0.755\end{array}$ & $\begin{array}{l}\text { MAAF } 1.3,4 \\
\alpha=0.700\end{array}$ & $\begin{array}{l}\text { MAAF } 1.2,3 \\
\alpha=0588\end{array}$ \\
\hline Maslow esteem needs & Deleted & $\begin{array}{l}\text { MAES } 1.3 .4 \\
\text { MASS } 1.2 \text { MASA } 4 \\
\alpha=0.779\end{array}$ & Deleted \\
\hline Maslow self-actualisation needs & $\begin{array}{l}\text { MASA } 1.2 .3 \\
\text { MAES } 2.4 \\
\alpha=0.807\end{array}$ & $\begin{array}{l}\text { MASA } 1,2,3 \\
\text { MASS } 4 \\
\alpha=0.755\end{array}$ & $\begin{array}{l}\text { MASA } 1,2.3,4 \\
\text { MAES } 2 \\
\alpha=0.701\end{array}$ \\
\hline Alderfer existence needs (pay) & $\begin{array}{l}\text { ALPY } 1,2,3.4 \\
\alpha=0.818\end{array}$ & $\begin{array}{l}\text { AL.PY } 3.4 \\
\alpha=0.879\end{array}$ & $\begin{array}{l}\text { ALPY } 1,2.3 .4 \\
\alpha=0.788\end{array}$ \\
\hline $\begin{array}{l}\text { Alderfer existence needs (fringe } \\
\text { benefits) }\end{array}$ & $\begin{array}{l}\text { ALFB } 1.2,3.4 \\
\alpha=0.902\end{array}$ & $\begin{array}{l}\text { ALFB } 1.2 .3 .4 \\
\alpha=0.900\end{array}$ & $\begin{array}{l}\text { ALFB } 1.2 .3 .4 \\
\alpha=0.892\end{array}$ \\
\hline Alderfer relatedness needs (superiors) & $\begin{array}{l}\text { ALRS } 1.2 .3 .4 \\
\alpha=0.794\end{array}$ & $\begin{array}{l}\text { ALRS } 1.2 .3 .4 \\
a=0.788\end{array}$ & $\begin{array}{l}\text { ALRS } 1,2.3 .4 \\
\alpha=0.788\end{array}$ \\
\hline Alderfer relatedness nceds (peers) & $\begin{array}{l}\text { ALRP } 1.2 .4 \\
\alpha=0.689\end{array}$ & $\begin{array}{l}\text { ALRP } 1.2 .3 .4 \\
\alpha=0.785\end{array}$ & $\begin{array}{l}\text { ALRP 1.2.3.4 } \\
\alpha=0.653\end{array}$ \\
\hline Alderfer grow th needs & $\begin{array}{l}\text { ALGR } 1.2 .3 .4 \\
\alpha=0.818\end{array}$ & $\begin{array}{l}\text { ALGR } 1.2 .3 .4 \\
a=0.792\end{array}$ & $\begin{array}{l}\text { ALGR } 1.2 .3 .4 \\
\alpha=0.789\end{array}$ \\
\hline McClelland (achievement) & $\begin{array}{l}\text { MCAC } 1.2 .3 .4 .5 \\
\text { MCPO } 1.2 .3 \\
\alpha=0.788\end{array}$ & $\begin{array}{l}\text { MCAC } 1.2 .3 \\
\text { MCPO } 3 \\
\alpha=0.728\end{array}$ & $\begin{array}{l}\text { MCAC } 1.2 .3 .4 .5 \\
\alpha=0.634\end{array}$ \\
\hline McClelland (power) & $\begin{array}{l}\text { MCPO } 4.5 \\
\alpha=0.627\end{array}$ & $\begin{array}{l}\text { MCPO } 1.2 .4 \\
\alpha=0.726\end{array}$ & $\begin{array}{l}\text { MCPO } 1.2 .4 .5 \\
\alpha=0.634\end{array}$ \\
\hline Performance intentions & $\begin{array}{l}\text { PERF 1.2.3.4 } \\
\alpha=0.717\end{array}$ & $\begin{array}{l}\text { PERF 1.2.3.4 } \\
\alpha=0.678\end{array}$ & $\begin{array}{l}\text { PERF 1,2,3.4 } \\
\alpha=0.727\end{array}$ \\
\hline
\end{tabular}


causal relationships (Hair et al., 1995: 696). Structural equation analysis, on the other hand, is based on causal relationships, in which the basic assumption is that a change in one variable results in a change in another variable (Hair $e t$ al., 1995: 626). The coefficients in a structural equation model represent theoretical cause and effect relationships among unobservable constructs (Hair et al., 1995: 696). In addition, structural equation modelling provides not only for controlling of extraneous and confounding variables, but also for the explicit modelling and estimation of measurement error (Hoyle, 1995: 10). Structural equation analysis is also regarded as a more flexible and comprehensive technique than other techniques, such as analysis of variance (ANOVA) and multiple regression, and therefore a more advanced and rigorous statistical technique to analyse attitudinal data (Hoyle, 1995: 10).

\section{Causal models for the influence of need satisfaction on} the employee job performance

Causal models to assess the influence of need satisfaction, as proposed by each of the three need theories (Maslow, Alderfer and McClelland), on the job performance of top

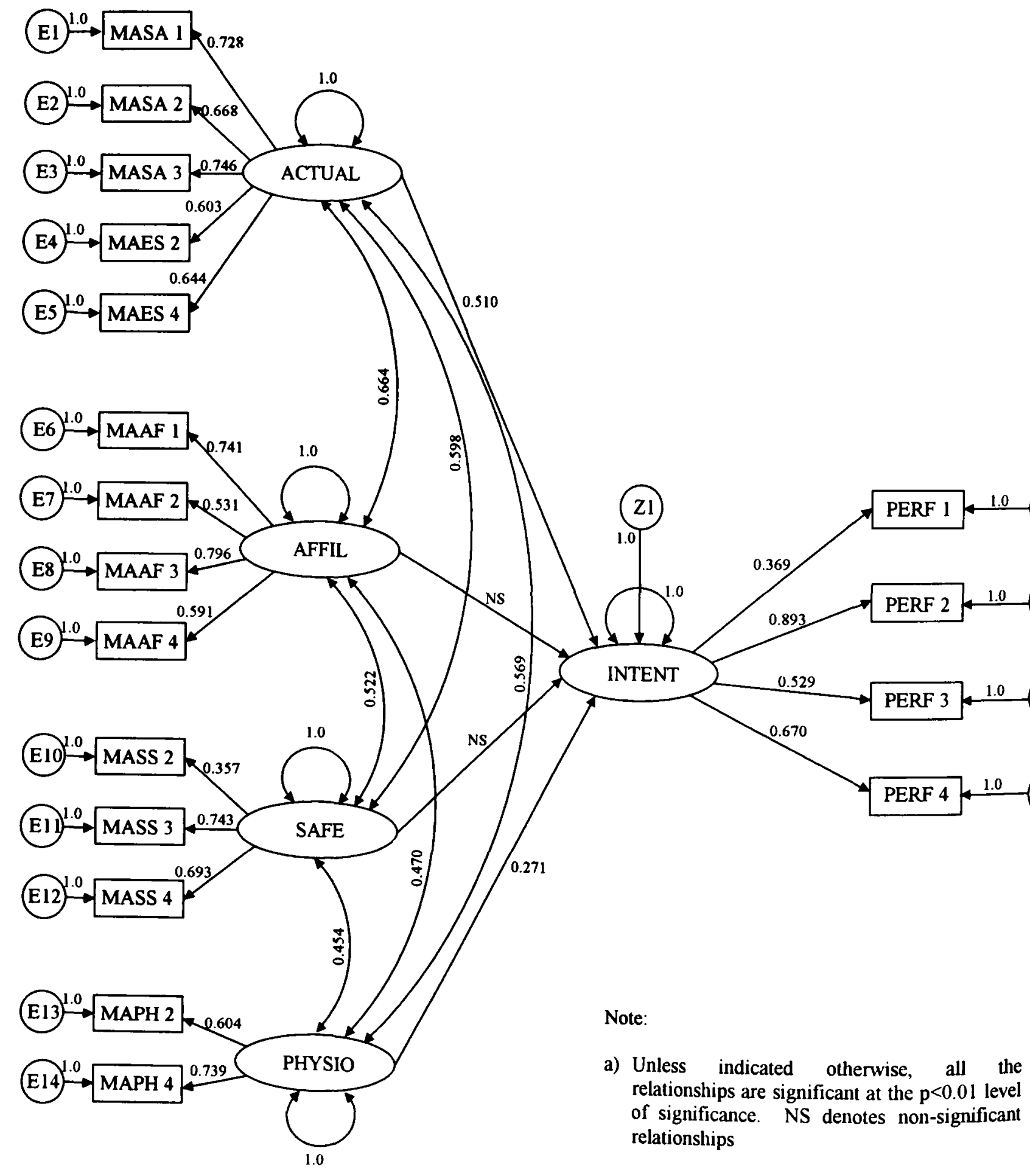

Figure 2 Path analysis model for the influence of need satisfaction on employee job performance: Maslow:s theory-top management 
managers, middle managers and frontline employees were constructed. Figure 2, for example, depicts the causal model constructed to investigate the relationship between the satisfaction of the Maslow needs and the job performance of top managers. The causal model was analysed by means of the computer program RAMONA (Browne \& Mels, 1996) and the results thereof are shown in Figure 2

Empirical results: the influence of the satisfaction of the Maslow needs on the job performance of top managers

Figure 2 shows that all the point estimates are significant at the 0.01 level of significance. The empirical results indicate that the satisfaction of self-actualisation needs is positively $(0.510, p<0.01)$ related to increased performance intentions. This means that the more the self-actualisation needs of top managers are satisfied the stronger their intention to improve their job performance will be. Top managers are therefore motivated by self-actualisation needs, a finding that lends some support to the Maslow theory of need satisfaction. On this basis Hypothesis 1, that higher-order (self-actualisation) need satisfaction exerts a positive influence on the job performance of top managers, is accepted.

The empirical results (Figure 2) show that the satisfaction of affiliation needs is not significantly related to the performance intentions of top managers. This means that acceptance by and a feeling of belonging to colleagues does not seem to play a big role in top managers' intentions to improve job performance. This finding provides indirect support to Maslow's theory that needs higher on the needs hierarchy, such as selfactualisation needs, will motivate top managers. Affiliation needs, which occupy a lower place on a top manager's need hierarchy, are therefore not strong motivators of top management's job performance.

The gratification of safety and security needs, such as job security, medical aid schemes and pension funds, also do not have a significant impact on the job performance of top managers. The position of chief executive officer seems to imply adequate job security with pension funds and medical aid benefits as given. According to Maslow's theory this finding is to be expected as safety and security needs are lower-order needs and therefore ought not to be strong determinants of the performance intentions of top managers.

Figure 2 also indicates that the satisfaction of physiological needs (money for food and clothes, time for relaxation, fumiture, a home) has a significant $(0.271, \mathrm{p}<0.01)$ impact on the performance intentions of top managers. This impact is in a positive direction which means that the higher the satisfaction of physiological needs the stronger the intention to improve job performance. This finding is however dissonant to Maslow's theory, which suggests that lower-order needs will not motivate top managers. The empirical results could, however, mean that top managers view the current material things they have acquired as an expression of some other valued outcome. The empirical results could further indicate a cultural bias, that the sampled top mariagers are more materialistically inclined than the managers on which Maslow based his original ideas.
Empirical results: the influence of the satisfaction of the Maslow, Alderfer and McClelland needs on the job performance of top managers, middle managers and frontline employees

The same analysis described above was replicated for all the other causal models and sub-samples (middle management and frontline employees). Figure 3 summarises the empirical results produced by the structural equation analyses. The need-progression proposition of Maslow is clearly visible in the empirical results (Figure 3). Based on the literature, it was expected that the satisfaction of higher-order (selfactualisation and growth) needs would have a significant influence on the top managers' performance intention $\left(\mathrm{H}^{\prime}\right)$. The literature also suggested that higher-order (esteem) needs would have a significant influence on the middle managers' performance intention and to a lesser extent top managers' performance intention $\left(\mathrm{H}^{2}\right)$. According to the literature the satisfaction of lower-order needs (affiliation, safety and physiological) would impact significantly on the performance intentions of frontline employees only $\left(\mathrm{H}^{3}\right)$.

Figure 3 shows that, as far as the Maslow and Alderfer theories are concerned, the satisfaction of self-actualisation and growth needs cause the performance intentions of top managers to increase. This finding further supported the acceptance of Hypothesis 1. Middle managers' performance intentions are enhanced by the satisfaction of esteem needs (Hypothesis 2 accepted), while the satisfaction of affiliation needs (and relations with peers) is more likely to increase the performance intentions of frontline employees (Hypothesis 3 accepted) The empirical results further show that higher-order (esteem and self-actualisation) need satisfaction exerts no influence on the job performance of frontline employees, which represents evidence in support of the need-progression theory.

The empirical results on the McClelland model show a departure from need-progression theory. The satisfaction of the achievement need, which is a higher-order need, is shown to be a significant determinant of employee job performance on all three job levels. It must however be noted that achievement (esteem) need satisfaction has the strongest impact on the performance intentions of middle managers (Hypothesis 2 supported), followed by top managers and then followed by frontline employees. This can be interpreted as an indirect substantiation of the need-progression theory.

To the extent that the need for power can be viewed as an esteem need (Kossen, 1991; Allen, Lucero \& Van Norman, 1997), the empirical results show no significant relationship between the power need satisfaction and job performance of top managers, middle managers and frontline employees. To this extent Hypothesis 2 that esteem need satisfaction (as measured by power needs) exerts a positive influence on the job performance of middle managers, would be rejected. It is however possible that none of the respondents in the subsamples identified with the use of personal (negative) power as it was defined in this study. A different result could have emerged if the influence of the satisfaction of social power, viewed in some quarters as positive power (Stahl, 1986), on the job performance of the three sub-samples was assessed.

The empirical result on the satisfaction of physiolngical needs, monetary remuneration in particular, supports the proposition that lower-order need satisfaction motivates 


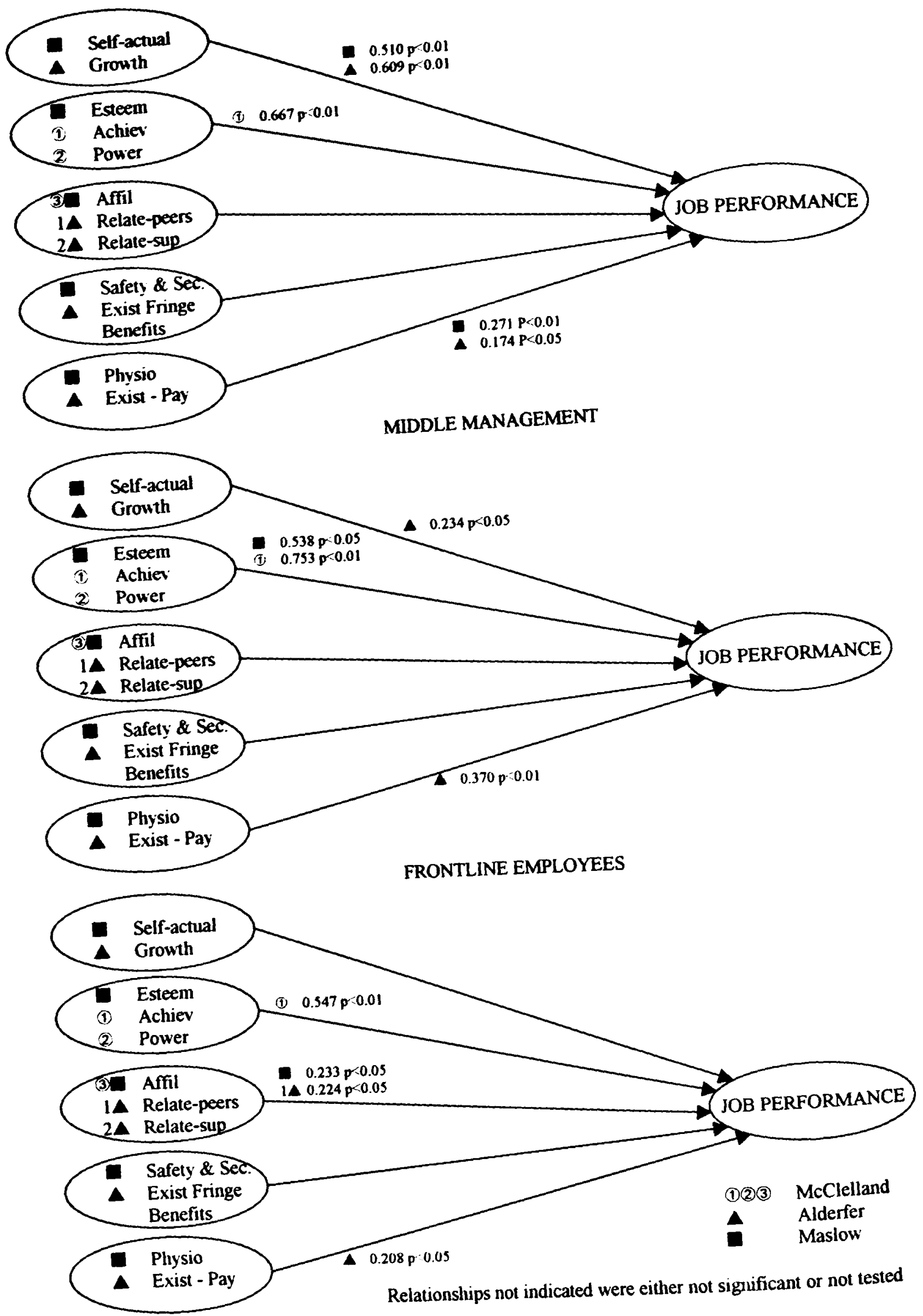

Figure 3 Influence of need satisfaction on employee job performance: a summary of the empirical results 
lower-level employees (Hypothesis 3). Figure 3, however, shows that middle and top managers are also motivated by the need for pay, a finding dissonant to the need-progression proposition. This finding simply adds to the debate as to whether monetary remuneration is a universal motivator or not (Fox, Scott \& Donohue, 1993; Levine, 1994; Hong et al., 1995).

\section{Indices of fit}

To establish the extent to which the above-mentioned models represent acceptable approximations of the data, the absolute fit indices (Hair et al., 1995: 659) of these models were examined. The absolute fit indices reported in the present study include the RMSEA (root mean square error of approximation) and the GFI (goodness-of-fit).

The RMSEA provides an indication to what extent the model fit obtained in the sample could be expected to be repeated in the population from which the sample was drawn. An RMSEA of less than 0.05 indicates a close fit, while an RMSEA of more than 0.08 represents a poor fit. An RMSEA of more than 0.05 , but smaller than 0.08 , indicates a reasonable or acceptable fit (Steiger \& Lind, 1980: MacCullam, Browne \& Sugaward, 1996). The GFI, believed to be one of the best absolute indices of model fit (Hoyle, 1995: 91), indicates the overall degree of fit of the hypothesised model on the data. The higher the GFI value in the range from 0 to 1 , the better the goodness of fit. Table 2 shows that all three motivation models produced RMSEAs and GFIs of a reasonable or an acceptable fit.

The above-mentioned fit indices all suggest acceptable approximations of the data and provides sufficient grounds for the acceptance of these empirical findings. The RMSEA values range from a close fit (Maslow-frontline employees model) to acceptable fit values for all the remaining models. All GFI indices are well above 0.8 , which indicates good fit.

\section{Summary of empirical findings}

The empirical results suggest that there is some evidence that need-progression does take place as employees ascend from lower-job levels to higher-job levels. Top and middle managers are primarily motivated by higher-order need satisfaction, while lower-level employees are essentially motivated by lower-order needs. It would therefore be beneficial to managers to take cognisance of this finding in their planning of reward packages, training and development programmes and career planning strategies.

Table 2 Fit indices

\begin{tabular}{llll}
\hline Fit indices & Maslow & Alderfer & McClelland \\
\hline $\begin{array}{l}\text { Top management } \\
\text { Absolute RMSEA }\end{array}$ & 0061 & 0.067 & 0068 \\
$\quad$ GFI & 0915 & 0873 & 0918 \\
Middle management & & & \\
Absolute RMSEA & 0061 & 0062 & 0053 \\
$\quad$ GFI & 0865 & 0849 & 0935 \\
Frontline employees & & & \\
Absolute RMSEA & 0042 & 0.064 & 0062 \\
$\quad$ GFI & 0915 & 0857 & 0927 \\
\hline
\end{tabular}

\section{Managerial implications}

\section{Top managers}

The empirical results revealed that top managers are primarily motivated by self-actualisation and growth needs, in other words, higher-order needs. This means that a challenging working environment that provides opportunities for creativity, self-fulfilment, advancement and autonomy is a key motivator of the job performance of top managers. The need for autonomy, creativity and advancement can be satisfied by putting the manager in charge of projects that have to be driven from the conceptual phase to the completion phase. It is believed that a person often experiences the feeling of self-fulfilment and creativity enhancement when a person starts and finishes a task.

Creativity must be managed and the core ingredient thereof is the demonstration of a strong orientation toward innovation (Amabile, 1995: 48-55). An organisational culture needs to be engendered that promotes a fair and constructive judgement of ideas, rewards and recognises programmes for creative work and provides for mechanisms for the development and active flow of ideas. Role models who set goals, support colleagues, value the contributions of top managers and show confidence in top managers need to be identified and inspired to play this role. Creativity teams, which include top managers and diversely skilled employees from various organisational levels, need to be established. These teams should interact, communicate, challenge, assist and commit themselves to the search for new ideas. The necessary resources in terms of funds, materials, facilities and information should be made accessible to those who want to be creative. Top managers should be allowed the freedom and autonomy to execute and control new initiatives. Impediments to creating a culture of creativity, such as unhealthy internal politics in the firm, destructive criticism of new ideas, negative internal competition, the tendency to avoid risk and the overemphasis on maintaining the status quo, must be avoided, reduced or eliminated.

The empirical results suggest that the performance intentions of top managers would be affected by their perceptions of advancement opportunities and personal growth. This is an indication to the human resources directors, in charge of identifying top management potential in the firm, to pay particular attention to promotion policies and programmes of their firms.

Promotion of top managers is often hindered by technical or managerial skill inadequacy and a lack of aptitude, development exposure and the inability to meet changing job requirements - a situation called personal plateauing. Upward mobility is also hampered by organisational plateauing, which occurs when firms have reached saturation point as far as human resources needs are concerned and therefore have to shed jobs. Individuals can also become organisationally plateaued as a consequence of age. internal competition among equally qualified candidates and affirmative action activities. The problem of plateauing must be effectively managed (McCampbell, 1996: 63). Firstly, by reducing the focus on promotion as a barometer of success. In this regard top managers need to be encouraged to seek fulfilment in their involvement in setting goals. determination of methods and procedures, more freedom for independent thought and action 
and the receiving of more authority. Secondly, top managers need to be assured of their importance to the organisation, while helping them to understand that plateauing is a natural development. In the third place, modifications to the organisational structure could be made so that horisontal positions are created with more significant responsibilities and concomitant autonomy.

Mentoring of younger managers could make a significant contribution to the satisfaction of top managers' self-actualisation needs. By being emulated as mentors, top managers would experience a sense of worth and recognition that they have actualised their life purpose by ploughing back their skills and knowledge into the organisation, profession or community. Putting top managers in charge of social responsibility programmes of firms is a further way to satisfy selfactualisation needs.

\section{Middle managers}

The empirical results showed that the satisfaction of esteem and growth needs have a significant impact on the job performance of middle managers. Growth need satisfaction influences middle managers to a lesser extent than top managers. This implies that the management of growth and self-actualisation need satisfaction also applies to middle managers

The major motivator of middle managers, however, is esteem need satisfaction, which mainly revolves around the search for achievement and recognition. Those in charge of motivating middle managers should therefore acquaint themselves with the characteristics of achievers to satisfy these needs of middle managers. Achievers are individuals who take moderate risks, set themselves challenging goals, have an intermal locus of control and self-motivation, search and explore new ways of doing things and are generally positive thinkers. An achieving environment for these achievers needs to be promoted (Dinsdale, 1990: 34). Firstly, by committing top management and training them in ways to encourage experimentation. Secondly, by the implementation of mentoring programmes for the 'fast lane' development of talented middle management protégés. In the third place, achievement development training by the mentor or an external consulting expert in the field needs to be conducted, which must be focused on practical job-related assignments and achievement behavioural training in goal-setting, assertiveness, problemsolving, risk-taking, independence and self-confidence. Lastly, rigorous feedback after intensive measurement or evaluation must be rendered.

Recognition is one of the most potent satisfiers of esteem needs. Recognition is an expression of acknowledgement, appreciation and approval of achievements, services and deeds. An effective recognition system based on sound principles needs to be introduced in all business firms (Glassock \& Gram, 1995: 96). These principles include sincerity (honest expression of appreciation), faimess and consistency, timeliness (immediate recognition of event), frequency (say thank you liberally), flexibility (showing appreciation in a variety of ways), appropriateness (recognition method should match effort, behaviour or result achieved), and specificity (recipients should know exactly what they are being thanked for and why their contribution is valuable). When introducing a recogni- tion system, the following steps are suggested (Glassock \& Gram, 1995: 96): (1) identify what management wants to achieve in terms of vision, mission, strategy, goals and objectives, and communicate it to all stakeholders; (2) determine and communicate to stakeholders the behaviours. practices and activities which will support the attainment of the vision, mission and goals; ( 3 ) select and communicate the tools that are to be used in the recognition system; (4) strive to show one hundred percent recognition to all desired behaviours and practices, trying to develop tools which address all possible situations and that are easy, available and can be initiated by anyone; and (5) continuously measure, monitor and improve the recognition system and convey this to all stakeholders.

\section{Frontline employees}

The empirical results revealed that frontline employees are mainly motivated by lower-order need satisfaction, including monetary rewards and affiliation needs. This finding focuses business managers' attention on the concept of gainsharing, the new buzzword in performance improvement programmes. It implies that lower-level employees want to be paid a fair wage and want to share in the gains of their improved job performance.

Gainsharing is an approach to enhance organisational effectiveness which embraces the whole firm through a formal system of employee involvement and financial bonuses based on job performance gains. Gainsharing has been found to im. prove employee productivity, organisational effectiveness, positive communication and problem-solving activities by individuals and groups. The concept differs from profit-sharing in that it spells out what everybody in the firm should do to achieve certain goals. Daily planning and performance feedback is the directive force behind the collective efforts of all employees. It is mainly focused on reducing costs, which results in the payment of weekly or monthly bonuses. Profitsharing, on the other hand, is not that specific in indicating exactly what each employee must do on a daily basis to improve profitability. Profit-sharing bonuses are paid out on an annual basis and employees often believe that managers will not keep their promises in paying out the profit bonuses. Profit bonuses are also perceived to focus only on higherlevel employees and not on lower-level employees. A practical application of gainsharing could include performance agreements between management and lower-level employees in which performance targets and concomitant remuneration are clearly spelt out.

The empirical results further showed that the satisfaction of affiliation needs (relatedness from peers in the Alderfer model) is a significant causal determinant of the job performance of frontline employees. This result suggests that frontline employees value the acceptance, belongingness and respect of their peers in their working groups. Destroyers of affiliation need satisfaction, such as downsizing or retrenchments, have been shown to impact negatively on employee goodwill, loyalty and morale. The effects of downsizing on survivors in enterprises include worries about long-term job security, a deep sense of loss, grief and depression and a drop in credibility and trust in management on the part of survivors. 
Retrenchments do not only impact negatively on people but have economic consequences, such as the erosion of buying power with the resultant unsold stocks and decreased profitability and further downsizing to increase profits. Slabbert (1996: 49) believes that unemployment could lead to the extinction of capitalism and suggests a paradigm shift in management thinking on profit-maximisation and job security. Profit-maximisation at the expense of job security will increasingly become intolerable among the poverty-stricken nations of the world. Slabbert is of the view that

'... reduced profit and redistribution of generated wealth over a wider spectrum of humanity are morally and economically sound ...' (1996: 49)

and should provide the philosophical foundation of management thinking in the future. Retraining of skills and proper career planning are proposed as a partial solution to the problem of downsizing and retrenchments.

\section{Need-progression and career planning}

The empirical results on need-progression hold important implications for career planning in firms. The results showed clear support for Maslow's belief that needs progress from lower-order needs to higher-order needs as employees ascend the organisational ladder. It would help managers to link need-progression to the different career stages employees experience in firms. Employees generally progress through four career stages in firms, namely the exploration (less than 30 years old), establishment ( 30 to 45 years old), maintenance (over 45 years old) and disengagement (preparation for retirement years) stages (Cron \& Slocum, 1986). During the exploration and establishment phases, where finding an occupation and establishing an initial professional image are the employee's prime concern, management would be well advised to focus on the lower-order need satisfaction of the new incumbent. A fair wage or salary, which is sufficient to satisfy the basic physiological needs, an adequate pension fund and medical aid and group insurance schemes to satisfy the security needs and induction programmes to satisfy the affiliation or belongingness needs, are the important needs in these first two career stages. The later years of the establishment stage are characterised by the search for achievement and recognition, which are both esteem needs. Management should then focus their motivational interventions on promoting achievement need satisfaction. Recognition of these achievements is also vital during this stage, which in turn will call for effective recognition systems early in the incumbent's career.

In the maintenance stage top managers usually try to maintain what they have achieved and start to search for ways to create new challenges. The management of creativity and plateauing will then form a large part of the motivational arsenal for the top managers in this career stage.

During the disengagement stage, management must prepare such employees for the transition from working to retiring During this stage the work pace and content must be reduced. There must however always be a guard against the feeling of exclusion and redundancy on the part of the person retiring. Dahl (1989) suggests that since these managers have progressed beyond self-actualisation need satisfaction. even higher needs such as '... be something for others. purpose in what we do, wholeness and togetherness ...' emerge. Management could utilise the experience and wisdom of retiring employees in the mentorship programmes and by so-doing satisfy the need of being of use (value) to others. This mentoring relationship can be extended in part-time consultations long after the retiring employee has left full-time employment.

\section{Pay and motivation}

The present study makes a significant contribution to the debate on whether monetary rewards motivate employees. Pay in some quarters is believed not to be a motivator (Levine. 1994: 77), while in other quarters pay has been found to be instrumental in satisfying other needs and in turn improving people's job performance (Fox et al., 1993: 690691 ). In the present study monetary rewards have been shown to be strong motivators of top management, middle management and frontline employees.

This finding has important implications for management. It could be an indication that a considerable number of the respondents are lacking in the satisfaction of basic needs, hence the demand for more pay. The need for more monetary rewards at all organisational levels could also indicate a strong materialistic inclination of the sampled respondents. In both cases this finding could predict a greater demand for wage and salary increases, which in turn would mean increased costs for firms.

The emphasis on pay satisfaction could further reveal the possibility that a large section of the sample has not as yet reached the stage where higher-order needs. such as esteem and self-actualisation needs, are the motivators of work behaviour. This could mean these respondents are still trying to eliminate job dissatisfaction and have not reached the stage when intrinsic motivation becomes important to them.

The question that has to be asked is whether employees at all job levels are to be paid more money? There appears to be two schools of thought developing on this question as far as the remuneration of top managers is concerned. The first point of view is that some top executives are not paid enough for the risks they take and the stress they have to bear. The second point of view argues for the limiting of top executives' salaries in the light of the absence of a pay-performance relationship that justifies the salary and the incremental new'spaper stories contrasting the large pas cheques of executives with the painful and emotion-laden lay off's of lower-level employees (Gibson. Ivancevich \& Donnelly, 1997: 182). Alfie Kohn as cited in Levine (1994: 78) suggests that employees on all organisational levels must be paid well and fairly and that every thing possible must then be done to help them forget about money by focusing on teamwork, participation and promoting a genuine interest in the job. In addition, the demand for fair remuneration from lower-level employees can be addressed via the avenues of performance agreements. gainsharing and social responsibility programmes of firms (the latter specifically directed at physiological need satisfaction). 


\section{Limitations and future research}

Although the present study has made significant contributions to the body of knowledge on motivation and employee productivity, certain areas still need to be explored or expanded. These areas include assessing the same model using other samples, the extension of the motivation models by the inclusion of various antecedents of needs and the investigation of the instrumental nature of need satisfaction. Another area for improving on the findings of the present study is the usage of improved measuring instruments. The inclusion of more measures of employee performance or productivity could also enhance the generalisability of the study.

\section{References}

Alderfer, C.P. 1967. Convergent and discriminant validation of satisfaction and desire measures by interviews and questionnaires, Journal of Applied Psychology. 51: 509-520.

Alderfer. C.P. 1969. An empirical test of a new theory of human needs. Organisational Behaviour and Human Performance. 4: 142-175.

Allen, R.E.. Lucero, M.A. \& Van Norman. K.L. 1997. An examination of the individual's decision to participate in an employee involvement program., Group and Organisation Management. 22(1): $117-143$.

Amabile, T.M. 1997. Motivating creativity in organisations: on doing what you love and loving what you do. California Management Review. 40(1): 39-58.

Aram, J.D. \& Piraino, T.G. 1978. The hierarchy of needs theory: an evaluation in Chile, Interamerican Journal of Psychologv, 12(2): $179-188$.

Barling, J.I. 1976. The application of Maslow's needs hierarchy and Bass's accelerate-decelerate formulation to three levels of mining personnel. Unpublished Masters dissertation. Johannesburg: University of Witwatersrand.

Blunt, P. \& Jones. M.L. 1992. Managing organisations in Africa. Berlin: Walter da Gruyter and Company.

Browne, M.W. \& Mels, G. 1996. Path Analysis: R.11ONA, SYSTAT 6.0 for Windows: Statistics. Chicago, Illinois, SPSS Incorporated. pp. $607-665$.

Carkhuff, R.R. 1986. Human processing and human productivity. Amherst, Massachusetts: Human Resource Development Press Inc.

Cranny, C.J., Smith, P.C. \& Stone, E.F. 1992. Job Satisfaction. How people feel about their jobs and how it affects their performance. New York: Lexington Books.

Cron, W.L., \& Slocum, J.W. 1986. The influence of career stages on salespeople's job attitudes, work perceptions, and performance. Journal of Marketing Research, XXIII: 119-129.

Cronbach, L.J. 1951. Coefficient alpha and the internal structure of tests, Psychometrika, 16: 297-334

Dahl, T, 1989. The corporation and its employees: a case study. Journal of Business Ethics. 8(8): 641-645.

De Cenzo, D.A. \& Robbins, S.P. 1988. Personnel/human resource management $4^{\text {th }}$ ed. Englewood Cliffs. New Jersey: PrenticeHall.

Dinsdale, R. 1990. The need for achievement is a driving force for success, Nursing RSA, S(5): 32-34.

Fox, J.B., Scott, K.D. \& Donohue, J.M. 1993. An investigation into pay valence and performance in a pay-for-performance field setting. Journal of Organisational Behaviour. 14(7): 687-693

Frane. J., Jennrich, R.I. \& Sampson, P.F. 1990. P4M-Factor analysis. In Dixon, W.J. \& Brown, M.B. Eds. B.MDP Statistical Softw'are Manual, 1: 311-337. Berkeley: University of California.

Gibson, J.L., Ivancevich. J.M. \& Donnelly, J.H. 1997. Organisations: behaviour, structure, processes. Chicago: Irwin Inc.

Glassock, S. \& Gram, K. 1995. Winning ways: establishing an effective workplace recognition system, National Productivity Review, 14(3): $91-102$.

Hair, J.F., Anderson, R.E., Tatham, R.L. \& Black, W.W. 1995. Multi- variate data analysis: With readings. Englewood Cliffs, New Jersey: Prentice Hall

Hampton, D.R., Summer, C.E. \& Webber. R.A. 1982. Organisational behaviour and practice of management. Glenview: Illinois: Scott. Foresman and Company.

Haywood-Farmer, J. \& Leenders. M.R. 1986. Psychological need profiles of purchasers, Journal of Purchasing and Materials Management, 22: 23-29

Hong. J.C.. Yang, S.D.. Wang, L.G.. Chiou, I.I .. Sun. F.Y. \& Huang. T.L. 1995. Impact of employee benefits on work motivation and productivity. International Journal of Career Management. (6): 10-14.

Hoyle. R.H. Ed. 1995. Siructural equation modelling: concepts, issues, and applications. London: Sage Publications. Inc.

Ivancevich. J.M. \& Matteson. M.T. 1999. Organizational hehavior and management, $5^{\text {th }}$ Ed. Boston: Mc(iraw-Hill Companies. Inc.

Jennrich. R.I. \& Sampson. P.F. 1966. Rotation for simple loadings. Psychometrika, 31: 313-323

Kossen. S. 1991. The human side of organisations. $5^{\text {th }}$ I:d. New York: Harper-Collins Publishers

Levine. H.Z. 1994. Why incentive plans cannot work. Compensation and Benefits Review: $26(1): 77-78$

MacCullum. R.C.. Browne. M.W. \& Sugawara. H.M. 1996. Power analysis and determination of sample size for covariance structure modelling. Psichological Methods. 1(2): 130-149.

Maslow, A.H. 1943. A theory of human motivation, Psychological Review. 50: 370-396.

McCampbell. A.S. 1996. Promoting productivity of plateaued managers by providing autonomy. Production and Inventory Management Journal, $37(1): 61-64$.

MeClelland, D.C. 1962. Business drive and national achievement, Harvard Business Review. 40: 99-112.

Pierce, J.I. \& Dunham, R.B. 1987. Organisational commitment: preemployment propensity and initial work experiences. Journal of Management. 13(1): 163-178.

Porter. L.W. 1962. Job attitudes in management: 1. Perceived deficiencies in need fulfilment as a function of job level. Journal of Applied Psychologl: 46(6): 375-384.

Porter. L.W. 1963. Job attitudes in management: II. Perceived importance of needs as a function of job level. . fournal of Applied $P$ sy. chologi: 47(2): 141-148.

Prokopenko. J. 1987. Productivity .1/anagement. a practical handbook. Geneva: International I abour Office.

Shore. L.M. Newton. L.A.\& Thornton III. G.C. 1990). Job and organisational attitudes in relation to employee behavioural intentions, Journal of Organisational Behaviour. II: 57-67.

Slabbert. A. 1996. Capitalism at the crossroads, International Journal of Social Economics, 23(9): 41-50

Stahl, M.J. 1986. Managerial and technical motivation: assessing needs for achievement, power and affiliation. New York: Praeger Publishers.

Steers. R.M. \& Braunstein. D.M. 1976. A behaviourally based measure of manifest needs in work settings, Journal of locational Behaviour, 9: 251-266.

Steers, R M. \& Porter. L.W. 1991. Motivation and work behaviour. $5^{\text {th }}$ Ed. New York: McGraw-Hill Inc.

Steiger. J.H. \& Lind. J.C. 1980. Statistically based tests for the number of common factors. Paper presented at the annual meeting of the Psychometric Society, lowa City. IA. May.

Stein, M. \& Hollowitz, J. 1992. Psyche at work: workplace applications of the Jungian Analytical Psychology. Wilmette. Illinots: Chiron Publications.

Sumerlin. J.R. \& Norman. R.L. 1992. Self-actualisation and homeless men: a known-group examination of Maslow`s hierarchy of needs, Journal of Social Behaviour and Personality. 7(3): 469481 .

Tharenou, P. 1993. A test of reciprocal causality for absenteeism, Journal of Organisational Behaviour, 14: 269-290.

Wahba. M.A.\& Bridwell, L.(j. 1976. Maslow reconsidered: a review of research on the need hierarchy theory. Organisational Behaviour and Human Performance, 15: 212-240. 